\title{
Growth kinetics, protease activity and histophagous capability of Uronema sp. infesting cultured silver pomfret Pampus argenteus in Kuwait
}

\author{
Ahmed Al-Marzouk*, I. S. Azad \\ Mariculture and Fisheries Department, Kuwait Institute for Scientific Research, PO Box No. 1638, Salmyia 22017, Kuwait
}

\begin{abstract}
Laboratory-produced and -reared sub-adults of silver pomfret (zobaidy) Pampus argenteus affected by severe scuticociliatosis during April and May 2005 were investigated and the causative was a scuticociliate, presumptively identified as Uronema sp. The parasite was capable of producing highly necrotic skin lesions. Mortalities started with a rise in the seawater temperature from 20 to $21.5^{\circ} \mathrm{C}$, coinciding with an increase in the total bacterial load of the rearing tank water from $10^{3}$ to $10^{5} \mathrm{CFU} \mathrm{ml} \mathrm{m}^{-1}$. The parasite was successfully cultured in vitro (85 passages), using $10 \%$ brain heart infusion broth inoculated simultaneously with an aquatic Vibrio sp. The parasite reached peak cell density $\left(1.82 \times 10^{5}\right.$ cells $\left.\mathrm{ml}^{-1}\right)$ on the third day of inoculation. The parasite cell count was found to be inversely related $(\mathrm{r}=-0.45)$ to the bacterial count in the incubation medium. The ciliate body dimensions measured, on average, $34.05 \pm 0.99 \mu \mathrm{m}$ in length and $16.70 \pm 0.74 \mu \mathrm{m}$ in width $(\mathrm{n}=300)$. Silver staining revealed morphological characteristics of Uronema sp., including a truncated anterior end, a buccal apparatus, caudal cilium and 3 oral polykinetids, with the first one appearing as a single row. Average number of kineties was $12 \pm 3$. There was an inverse relationship $\left(\mathrm{R}^{2}=0.84\right)$ between the proteolytic activity and the number of in vitro passages of the scuticociliate. However, the parasite from a freshly infected fish (using inoculum from the tenth passage) showed higher proteolytic activity (31.2\%) compared with that produced by the inoculum from in vitro cultures $(9.75 \%)$. The ciliate also showed a distinct histophagous capability when tested in vitro using host muscle tissue.
\end{abstract}

KEY WORDS: Silver pomfret • Zobaidy · Pampus argenteus · Scuticociliate • Uronema sp. • Growth kinetics $\cdot$ Protease activity $\cdot$ Histophagous ability

\section{INTRODUCTION}

The silver pomfret Pampus argenteus (locally known as zobaidy) is a valuable food fish with a wide geographical distribution from the East China Sea to Southeast Asia, the Indian Ocean, Arabian Gulf and the North Sea (Davis \& Wheeler 1985). It commands the topmost list price and demand in Kuwaiti markets. Because of its high value, this species is now being assessed for its aquaculture potential in Kuwait. Successful egg collection, fertilisation, hatching and larval development (Almatar et al. 2000) have been achieved. The most devastating parasitic disease of $P$. argenteus is caused by the ciliated protozoan Uronema sp. (Al-Marzouk et al. 2004), which produced high mortalities among different sizes of cultured $P$. argenteus during 2000 and 2004. Uronema sp. is a histophagous ciliate and characterised by its potential for invading systemically and destroying fish tissues (Kwon et al. 2003). Uronema spp. are free-living ciliated protozoans that can cause fatal infections in marine fish (Cheung et al. 1980, Bassleer 1983, Watts et al. 1996, Munday et al. 1997).

Proteases have been shown to play an important role in host-tissue invasion and digestion of host proteins 
(McKerrow 1989). It has also been reported that the cysteine proteases in parasitic protozoans play a role in protein degradation (North 1992). It has been shown that metalloproteases excreted by Uronema marinum are involved in the invasion of host tissues (Lee et al. 2003).

The objective of the present study was to determine in vitro the growth kinetics of Uronema sp. to variations in temperature and nutrient concentrations. In addition, protease activity and histophagous capability were also determined.

\section{MATERIALS AND METHODS}

Fish and isolation of the scuticociliate. Cultured Pampus argenteus $(34.24 \pm 10.02 \mathrm{~g}, 12.47 \pm 6.44 \mathrm{~cm})$ reared in $300 \mathrm{~m}^{3}$ concrete tanks supplied with flowthrough filtered aerated seawater (35 to $501 \mathrm{~min}^{-1}$, salinity 39 to $42 \mathrm{ppt}$ ) were used in the present study. The fish were produced in the laboratory of the Mariculture and Fisheries Department of the Kuwait Institute for Scientific Research, through artificial spawning of wild broodstock. The fish suffered a disease outbreak due to the scuticociliate in April and May of 2005. Moribund infected fish with characteristic clinical manifestations of a scuticociliate infection were examined. Skin scrapings were observed using a compound microscope to detect the presence of the ciliate. Ciliates obtained from the infected fish were resuspended in sterile $10 \%$ brain heart infusion broth (Hi Media) in seawater (SBHIB) for growth, inoculated simultaneously with the bacterium (Vibrio sp.) that was found associated with the skin lesions. The scuticociliate so grown in the broth was used for further investigations on parasite morphology, growth kinetics, protease activity and histophagous capability.

Parasite morphology. Wet mounts of Uronema sp. from both skin scrapings and the culture media were observed under the microscope for recording the cell morphology. Phase contrast microscopy and silverstained ciliates were used to reveal the kineties, caudal cilium oral polykinetids and the macronucleus. Cell size (length and width) was measured using a calibrated ocular micrometer and the number of kineties was also counted. Three random samples (20 cells sample $\left.{ }^{-1}\right)$ in each category were used for the measurements.

Silver staining. The parasite grown in dilute SBHIB $(10 \% \mathrm{v} / \mathrm{v}$ in sterile seawater) was used for silver staining. The $3 \mathrm{~d}$ old culture suspension was passed through a $1 \mu \mathrm{m}$ syringe filter, and the parasite was washed using sterile PBS (phosphate-buffered saline) followed by freshwater. Silver staining was done following Foissner (1992) with some modifications. Briefly, the washed ciliates were fixed for $1 \mathrm{~h}$ in $6 \%$ (v/v sterile PBS) buffered formalin and centrifuged at $500 \times g$ for $10 \mathrm{~min}$; the pellet of cells was resuspended in distilled water and centrifuged 3 times, washing the pellet each time with distilled water. The final pellet was made into a thick cell suspension using $1 \mathrm{ml}$ distilled water, and $50 \mu \mathrm{l}$ of the suspension was smeared over microscopic slides precoated with $1 \%$ bovine serum albumin (BSA) and dried in an oven at $40^{\circ} \mathrm{C}$ for $1 \mathrm{~h}$. The slides were flooded with $2 \%(\mathrm{w} / \mathrm{v})$ silver nitrate and stained for $10 \mathrm{~min}$. The slides were rinsed and irradiated under a UV lamp for $20 \mathrm{~min}$, air dried, dehydrated in graded ethanol, cleared in xylene and mounted using DPX. Observations were made under a compound microscope, and the images were captured using a digital camera.

Growth kinetics under different nutrient concentrations. Uronema sp. was cultured using 0, 5, 10, 25, 50 and $100 \%$ SBHIB. A starter culture was prepared using skin scrapings from infected fish, incubated for $24 \mathrm{~h}$ in $10 \%$ SBHIB (w/v in sterile seawater). Then, $1 \mathrm{ml}$ of the starter culture, corresponding to $10^{3}$ ciliates $\mathrm{ml}^{-1}$ (counted using a haemocytometer counting chamber), was inoculated into $250 \mathrm{ml}$ conical flasks containing $200 \mathrm{ml}$ of different concentrations of SBHIB. The flasks were incubated at 27 to $28^{\circ} \mathrm{C}$ using a thermostatcontrolled water bath for $4 \mathrm{~d}$. No antibiotic was added to the culture medium, to facilitate the growth of bacteria to serve as food for the scuticociliate. Daily samples were drawn from the flasks and inactivated using $5 \%$ formalin for the enumeration of the parasite population. Random samples of 10 drops of $5 \mu \mathrm{l}$ each on a glass slide were observed and counted under the microscope. The scuticociliate counts from random samples of 10 such drops from each flask of different SBHIB concentrations were used to obtain the ciliate population density in the flask. The suspensions were appropriately diluted when the cell density was $>100$ per $5 \mu \mathrm{l}$ of the suspension. The average number of cells per day, during the $4 \mathrm{~d}$ culture under different nutrient concentrations, was calculated and compared.

Growth kinetics of scuticociliate under different incubation temperatures. Keeping the nutrient concentration constant at $10 \%$ of SBHIB, 4 incubation temperatures $\left(19,23,30\right.$ and $\left.40^{\circ} \mathrm{C}\right)$ were tested for evaluating the growth kinetics. Triplicates in each treatment, as explained above, were used for the enumeration of the ciliate population during the $4 \mathrm{~d}$ incubation period.

Growth kinetics of scuticociliate and total bacterial count. Growth medium containing 10\% SBHIB was selected to study the population growth pattern of in vitro cultures of the ciliate incubated at room temperature $\left(27\right.$ to $\left.28^{\circ} \mathrm{C}\right)$. Then, $1 \mathrm{ml}$ of the starter, corresponding to a cell density of $10^{3} \mathrm{cells} \mathrm{ml}^{-1}$ of the ciliate and $10^{7} \mathrm{CFU} \mathrm{m} l^{-1}$ of Vibrio sp., was inoculated in $250 \mathrm{ml}$ 
flasks containing $200 \mathrm{ml}$ of $10 \%$ SBHIB and incubated at room temperature. Enumeration of the ciliate was carried out as explained above, and bacterial enumeration was carried out using BHI agar with a $2 \%$ final salt concentration (w/v NaCl). Growth kinetics of both the ciliate and the bacterium were analysed for a $15 \mathrm{~d}$ culture period.

Protease activity. Uronema sp. was grown in $10 \%$ SBHIB to produce different passages from an initial inoculum obtained from diseased Pampus argenteus, as explained above. Subcultures of the ciliate were produced on every third day using SBHIB (10\% v/v) to obtain successive subcultures, which were designated as $\mathrm{P} 1, \mathrm{P} 2, \ldots$ etc. up to $\mathrm{P} 15$, representing passage numbers.

A repassage of Uronema sp. in live Pampus argenteus was obtained by injecting (i.m.) the fish with $10^{4}$ ciliates and reisolating the ciliate from the blood $2 \mathrm{~d}$ after experimental infection. The repassed ciliate was separated from the serum for further passages as explained above. The first, third and fifth successive passages of this inoculum were designated RP1, RP3 and RP5, respectively.

The exponential growth phase of the ciliate (third day after inoculation) was used for determining the protease activity. The culture suspension was further treated to obtain 3 sample types for determining the protease activity. It was filtered through a sterile $1 \mu \mathrm{m}$ syringe filter, and the resultant filtrate (containing only the growth medium and bacteria) was designated as scuticociliate-free suspension (SF). The second sample was a filtrate obtained after $0.2 \mu \mathrm{m}$ filtration, resulting in bacterium-free suspension (BF). The third sample consisted of unfiltered culture suspension (CS) containing the scuticociliate, bacteria and growth medium.

The above samples (SF, BF and $\mathrm{CS}$ ) were allowed to react with standard protein $\left(100 \mu \mathrm{g} \mathrm{ml} \mathrm{m}^{-1}\right.$ of BSA [Sigma] in sterile PBS) for $1 \mathrm{~h}$ at room temperature (27 to $28^{\circ} \mathrm{C}$ ). Protein content of the incubated standard BSA was estimated by colorimetric protein assay (Bradfold 1976) for computing the digestive capability index of the protease present in different samples.

Protease activity due to the scuticociliate was obtained by deducting the protease activity of SF sample from that of the CS. The protease activity was expressed as percent digestibility of incubated protein.

Histophagous capability in vitro assay. The scuticociliate in vitro cultures (third day) were used to study the histophagous muscle digestibility. A healthy subadult Pampus argenteus (42 g) was sacrificed to obtain lateral muscle blocks of uniform size $\left(10 \mathrm{~mm}^{3}\right)$ along with the skin. The muscle blocks were soaked for $1 \mathrm{~h}$ in sterile PBS containing $50 \mathrm{ppm}$ of oxytetracycline to inhibit the growth of bacteria associated with the mus- cle blocks. The muscle blocks were incubated with the size-graded samples SF, BF and CS obtained from the ciliate culture as explained above. Muscle blocks in triplicates and the respective samples were incubated in $50 \mathrm{ml}$ plastic sterile tubes with lightly capped lids. The muscle blocks obtained from the fish were randomised for assigning replication and treatment blocks, using online randomiser software (www. randomizer.org). Tubes containing the muscle block and sterile PBS ( $\mathrm{pH}$ 7.2) were used as controls. The tubes were incubated at room temperature for $3 \mathrm{~d}$, and the muscle blocks were rinsed lightly, allowed to stand on blotting paper for $5 \mathrm{~min}$ and weighed. The weight loss was calculated by deducting the weight recorded at the end of the experiment from that at the start of the experiment. The weight loss was expressed as the histophagous capability percent of SF, BF and CS.

Statistical analysis. Different parameters in each experiment were tested separately using a 2-way ANOVA, to evaluate the effect of days of culture, temperature of incubation and nutrient concentrations on the ciliate population. The correlation coefficient (r) was estimated to show the relationship between the growth kinetics of the ciliate and the bacteria in the culture medium.

The coefficient of determination $\left(\mathrm{R}^{2}\right)$ was calculated to reflect the relationship between the number of in vitro passages and the protease activity. Also, a logarithmic trend line was fitted using Excel (MS Office $\mathrm{XP}$ ). Tukey's multiple comparison was used to test the significance of differences between the digestive capability in the histophagy experiment.

\section{RESULTS}

\section{Morphology of ciliates}

The ciliate was variable in size, ranging from 24.7 to $40.0 \mu \mathrm{m}$ in length and 12.5 to $20.2 \mu \mathrm{m}$ in width $\mathrm{n}=$ 300). Silver-nitrate staining revealed information on the somatic kineties and oral polykinetid (opk). The ciliate was generally elongated, with a rounded posterior end, truncated anterior end devoid of cilia and a clear contractile vacuole at the posterior end (Fig. 1a,b). The number of somatic kineties ranged from 12 to 14 ( 7 rows clearly visible), the macronucleus measured from 5 to $6 \mu \mathrm{m}$, while the caudal cilium ranged from 7 to $11 \mu \mathrm{m}$, which was approximately twice the length of the somatic cilia (Fig. 1a). The buccal apparatus showed 3 oral polykinetids (opk1, opk2 and opk3), with presumably a single row in opk1 and a double row in opk2 (Fig. 1c). Hence, the ciliate isolated from diseased Pampus argenteus was considered Uronema sp. 


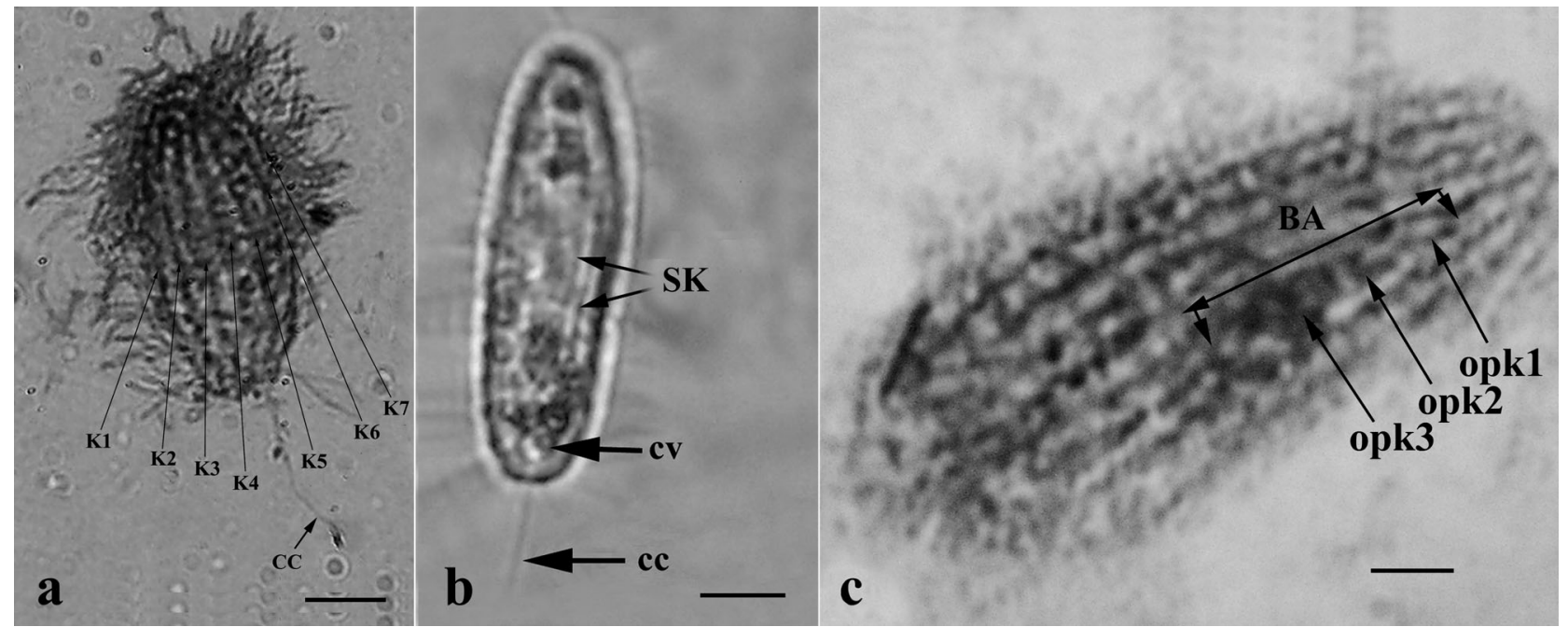

Fig. 1. Uronema sp. (a) Silver-stained ciliate showing kineties (K1 to K7) and caudal cilium (CC). (b) Wet mount of the ciliate showing contractile vacuole (cv) and somatic kineties (SK). (c) Silver-stained ciliate with buccal apparatus (BA) and oral polykinetids (opk1, opk2 and opk3). Scale bars $=(\mathrm{a}, \mathrm{b}) 3 \mu \mathrm{m}$; (c) $5 \mu \mathrm{m}$

\section{Growth kinetics of the scuticociliate under different nutrient concentrations}

The parasite proliferation in different broth concentrations reached its peak on the third day of inoculation, and the highest number was noted in the $10 \%$ broth concentration. The difference between the cell populations in different broth concentrations was highly significant. The $3 \mathrm{~d}$ old culture $(3 \mathrm{doc})$ showed significant difference in ciliate numbers, especially at 5 and $10 \%$ broth concentrations (Fig. 2). Population

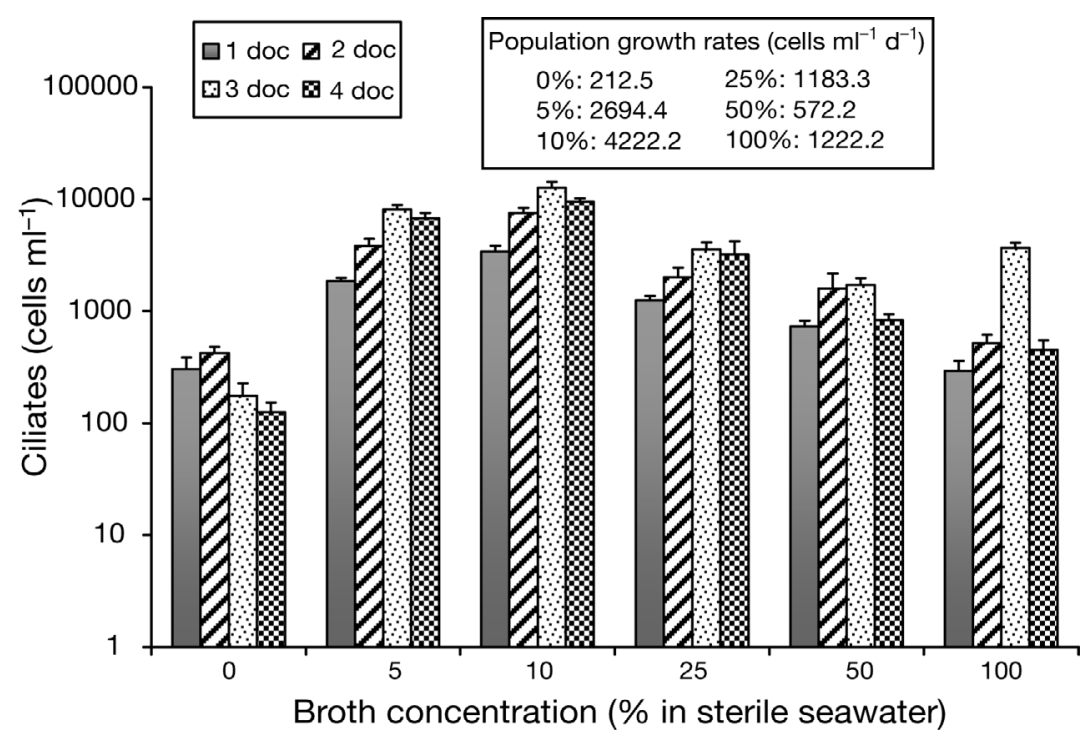

Fig. 2. Uronema sp. Growth kinetics of the ciliate under different brain heart infusion broth concentrations. Error bars indicate SD. doc: day old culture growth was highest in $10 \%$ SBHIB (4222.2 cells $\mathrm{ml}^{-1}$ $\left.\mathrm{d}^{-1}\right)$ followed by $5 \%$ SBHIB $\left(2694.4\right.$ cells $\left.\mathrm{ml}^{-1} \mathrm{~d}^{-1}\right)$.

\section{Cell count of the scuticociliate and total bacterial count}

Trends in the proliferation of the ciliate in relation to the bacterial population in in vitro cultures are depicted in Fig. 3. The parasite showed an inverse relationship $(\mathrm{r}=-0.45)$ with bacterial counts in the culture medium, especially during the first week of the culture period. The peak ciliate population was recorded on the third day of culture, with a sharp decline in bacterial count. However, there was a decline in the ciliate numbers at Day 5, stabilising to densities of 70000 to 80000 ciliates $\mathrm{ml}^{-1}$ from Day 6 onwards.

\section{Growth kinetics of the scuticociliate under different incubation tempera- tures}

Optimum temperature for scuticociliate proliferation was found to be $30^{\circ} \mathrm{C}$, although peak parasite densities were noted in the culture suspensions incubated at 30 and $40^{\circ} \mathrm{C}$ on the third day of incubation. The incubation temperature did not significantly influ- 


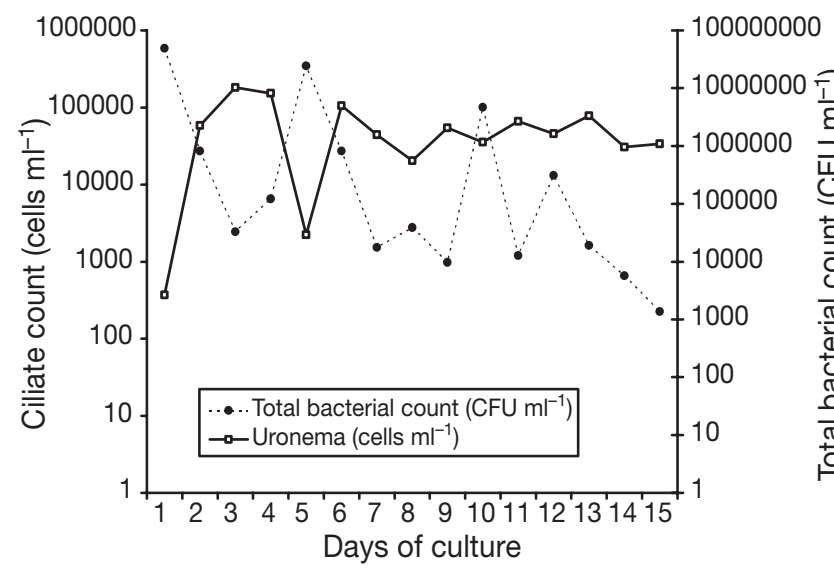

Fig. 3. Uronema sp. Relationship between ciliate cell count and total bacterial (Vibrio sp.) count during $15 \mathrm{~d}$ of culture. CFU: colony-forming units

ence the cell number up to $2 \mathrm{~d}$ post-incubation. Clear and significant $(p<0.05)$ influence of the incubation temperature was noted on the third day (Fig. 4).

\section{Protease activity of the scuticociliate}

Proteolytic activity (Fig. 5) of the scuticociliate showed a steady decreasing trend with in vitro passages (46.75\% in P1 to $7.31 \%$ in P15). Repassed ciliates (using the inoculum of Passage 10) showed significantly higher proteolytic activity $(31.19 \%$ in RP1 and $23.92 \%$ in RP5). Proteolytic activity and successive passages of the scuticociliate were inversely related $\left(\mathrm{R}^{2}=0.84\right)$.

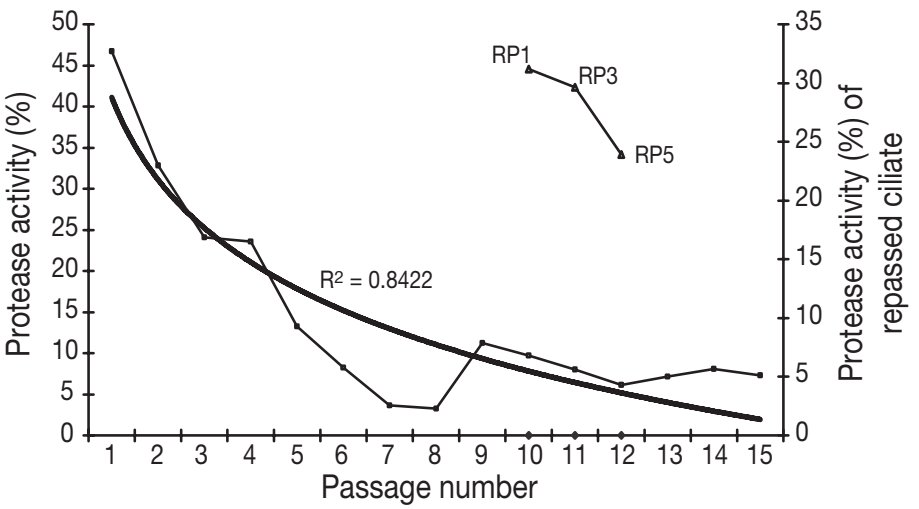

Fig. 5. Uronema sp. Protease activity of the ciliate during in vitro passages and repassages (RP1, RP3 and RP5). The smooth curve reflects the exponential trend, and the coefficient of determination $\left(\mathrm{R}^{2}\right)$ represents the relationship between passages and protease activity. The trend for repassages is also depicted (against dotted line on $X$-axis)

\section{Histophagous capability of the in vitro scuticociliate suspension}

Naturally infected Pampus argenteus showed severe necrotic skin lesions, and the histophagous activity of the scuticociliate was reflected in the in vitro results (Fig. 6) Histophagous activity of the scuticociliate in association with the bacteria (CS) showed the highest digestive capability $(42.46 \pm 6.72 \%)$. The digestive capability of bacteria- and scuticociliate-free suspension $(\mathrm{BF})$ was lower $(7.63 \pm 3.81 \%)$ compared with the scuticociliate-free bacterial suspension (SF, $25.37 \pm$ $2.06 \%)$. Each of the treatments were significantly $(\mathrm{p}<$ 0.05) different from one another as tested by Tukey's test of honestly significant differences (11.56).

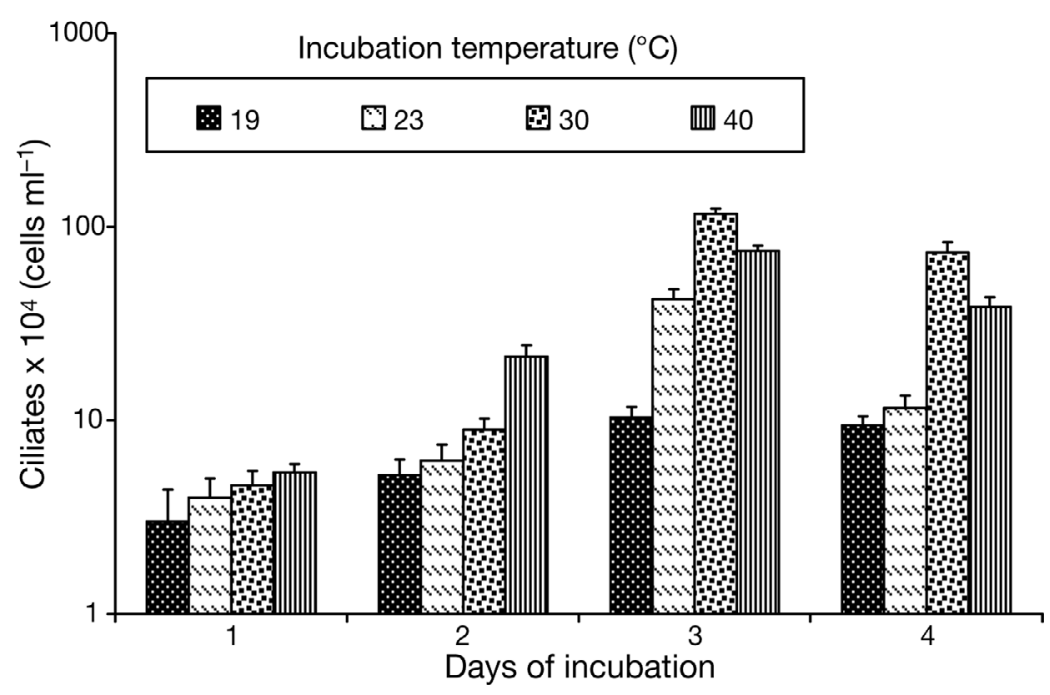

Fig. 4. Uronema sp. Growth kinetics of the ciliate under different incubation temperatures during $4 \mathrm{~d}$ of incubation. Error bars indicate SD

\section{DISCUSSION}

The ciliate isolated in the present study was identified as a scuticociliate, most probably Uronema sp. on the basis of its morphology (ciliature, buccal apparatus and kineties) and its ability to cause necrotising skin lesions. It was noted that this ciliate showed distinct histophagous ability, acting deleteriously on the skin and damaging host muscle. The observations made in our study compare well with the results of Mundy et al. (1997). Accordingly, on the basis of ciliate size, the number of somatic kineties, alignment of the caudal cilium, position of the contractile of the vacuole, and length 


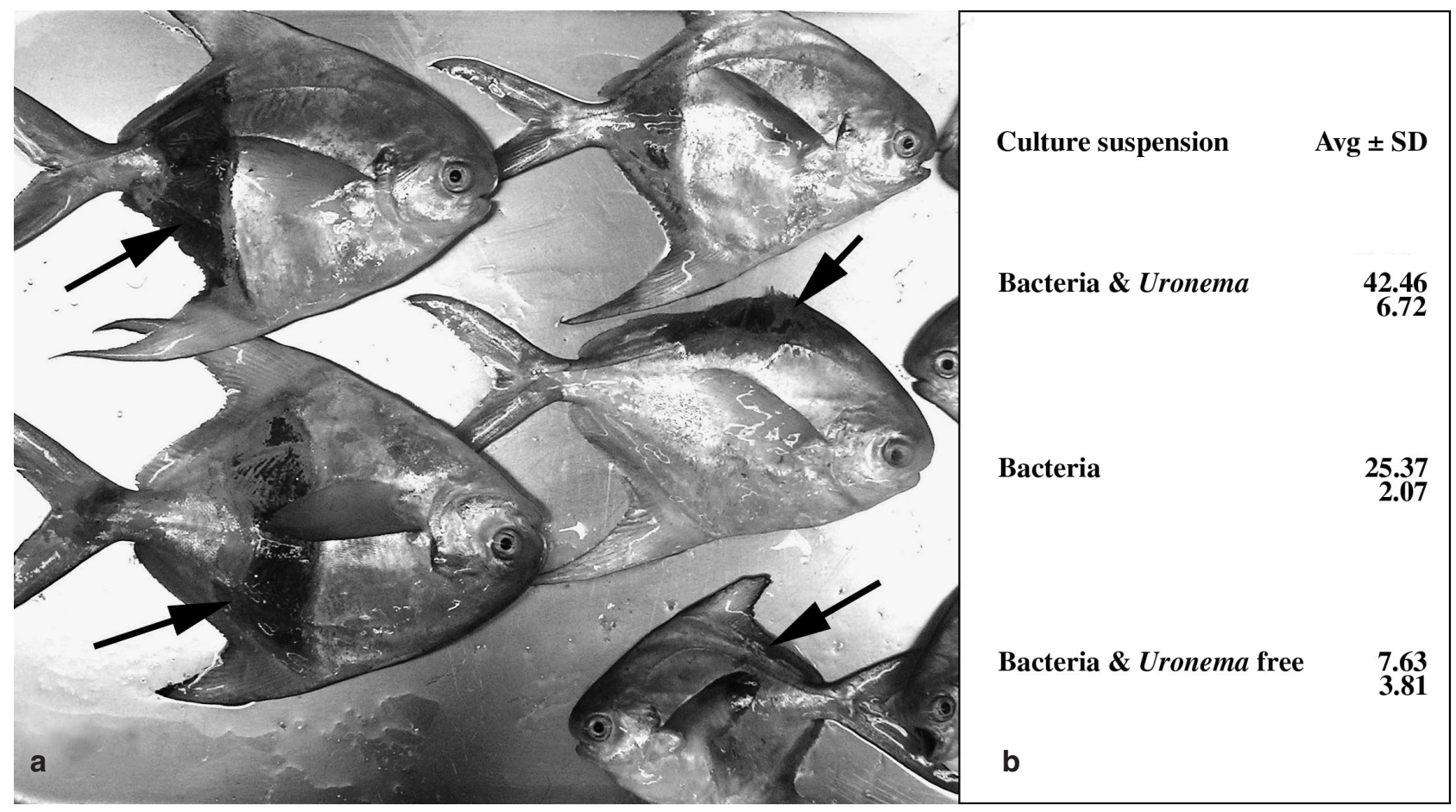

Fig. 6. Pampus argenteus infected by Uronema sp. (a) Silver pomfret with severe skin lesions caused by the ciliate. (b) In vitro histophagous capability (\%) of culture suspension of the ciliate

and position of the oral apparatus, the present isolate can be considered as belonging to the genus Uronema and, hence, is designated Uronema sp.

Growth curves for both ciliate and bacteria illustrated a typical predator-prey relationship. Bacterial proliferation produced peak cell densities before those of ciliates, and thus served as food for the slowly proliferating ciliates. As the ciliates increased in numbers, the bacterial count decreased. This could be the reason for an initial proliferation of the parasite in the natural pathogenic environments supported by rich organic and bacterial loads. Stabilisation of the parasite population, even with a decrease in the bacterial population, could be explained by the survival mechanisms of the parasite. Kimball et al. (1959), studying the growth and proliferation of Paramecium, suggested that the process of controlling cell division may be less sensitive to decreased food consumption than that controlling cell growth. This could be one of the reasons for sustained cell density in the nutrient-depleted culture condition in the present study. Hamilton \& Preslan (1969) gave an account of the earliest studies of the growth characteristics of the pelagic Uronema sp., and reported that, as food supply decreases, it will be to the advantage of the organism to maintain its numbers. Thus, survival under such conditions would be possible despite reduced bacterial load, as recorded in the present study. The decline in cell population of the scuticociliate in the present study and a clear inverse relationship between the bacterial and ciliate populations during most of the study can be explained by the bacteriovorous nature of scuticocilates of the genus Uronema. This has been experimentally proved on several occasions (Fenchel 1968, Hamilton \& Preslan 1969, Parker 1976, Ohman \& Snyder 1991). It has also been observed that Uronema digests bacteria faster than other abundant ciliates, e.g. Strombidium or a mixture of spirotrich ciliates (Sherr et al. 1988). Pinocytosis could be a means of acquiring nutrients for some ciliates. The survival of ciliates under the nutrient-depleted circumstances in the present study was probably a result of complex nutrient-utilisation mechanisms, of which pinocytosis might have been important in supplying nutritional substances when bacteria are lacking. Also, the survival mechanisms of parasitic ciliates (Hamilton \& Preslan 1969) and pinocytosis were responsible for allowing the scuticociliate to sustain its population in the present study. However, carefully designed in vitro studies on these aspects could provide more conclusive answers to the stability of scuticociliate populations under nutrient-deprived conditions.

Though the parasite was found to multiply at all 4 incubation temperatures used in the present study, 
$30^{\circ} \mathrm{C}$ was the optimal temperature for proliferation of the ciliate. The biological characteristics of the ciliate studied here are similar to those reported by Cheung et al. (1980); they noted wide fluctuations in temperatures $\left(8\right.$ to $\left.28^{\circ} \mathrm{C}\right)$ during an epizootic event caused by Uronema marinum. Working on the differences between the short- and long-term cultures of $U$. marinum, Kwon et al. (2003) recorded significantly higher protease activity in short-term cultures of the parasite at $30^{\circ} \mathrm{C}$ than at $20^{\circ} \mathrm{C}$. Warmer temperatures also influenced the cell proliferation of Tetrahymena corlissi isolated from guppy in Thailand (Hatai et al. 2001), where the freshwater ciliate grew optimally at 25 to $30^{\circ} \mathrm{C}$.

Parasitic protozoans are known to derive potential benefits from the proteases they secrete, which have both metabolic and physiological functions (McKerrow 1989, North 1992, McKerrow et al. 1993, Klemba \& Goldberg 2002). Lee et al. (2003) reported that Uronema marinum associated with olive flounder Paralichthys olivaceus secrete proteases during in vitro culture. Our findings in the present study revealing the abilities of the parasite to produce protease conform with the observations of previous workers. Hence, the enzyme produced by the parasite may play an important role in the establishment and progression of the disease. An interesting feature of the present study was that the parasite obtained from a freshly infected fish produced significantly higher levels of proteases than the parasite from in vitro cultures. Hence, the ciliate in the repassage was more virulent, producing higher proteolytic activity. These observations indicate that the ciliate becomes more virulent after passing through a natural host. Similarly, Kwon et al. (2003) concluded that the infection potential of Uronema marinum may be related to its protease activity. Also, the scuticociliate-free culture suspension (SF) produced considerable proteolytic activity, probably contributed by the Vibrio sp. used in the inoculation medium as food for the growing parasite. It has been reported earlier that some of the vibrios and aeromonads also produce proteases contributing to their pathogenicity in fish (Nottage \& Birkbeck 1987, Arnesen et al. 1995). The proteolytic activity noted in the suspension free of both the ciliates and bacteria (BF) in our study is due to the protease released by the parasites and bacteria into the medium. The ciliate counts and the protease activity after 8 passages showed a stabilising trend. Our results suggest that the bacterially aided infection by the ciliate in Pampus argenteus was probably responsible for the initiation of scuticociliatosis, and, as the ciliate proliferated, it relied on its histophagous abilities and enhanced protease activity to spread the disease.

Liquifactive muscle necrosis is one of the consistent and widely reported clinical manifestations of scutico- ciliatosis in marine fish (Cheung et al. 1980, Munday et al. 1997, Kwon et al. 2003, Lee et al. 2003). Though there are no reports of in vitro histophagous capability assays of fish tissue, the results of the present study can be compared with the high muscle protein digestibility by a ciliate parasite in Norwegian lobster Nephrops norwegicus (Small et al. 2005).

The histophagous ability of the present ciliate indicates that it is highly invasive and destructive, causing wide-spread necrotic lesions on the skin. Further research on protease neutralisation strategies can help in reducing the lesions and probably the losses due to scuticociliatosis in Pampus argenteus and other marine fish.

Acknowledgements. Sincere thanks to Dr. Sulaiman Almatar for his encouragement and supply of fish.

\section{LITERATURE CITED}

Al-Marzouk A, Duremdez R, Al-Gharabally H (2004) Efforts to control outbreaks of diseases among cultured silver pomfret Pampus argenteus in Kuwait. J Aquacult Trop 19: $103-110$

Almatar S, Al-Abdul Elah K, Abu-Rezq T (2000) Larval developmental stages of laboratory reared silver pomfret, Pampus argenteus. Ichthyol Res 47:137-141

Arnesen JA, Eggset G, Jørgensen TO (1995) Partial purification and characterisation of extracellular metalloproteases from Aeromonad salmonicida spp. J Fish Dis 18:283-295

Bassleer G (1983) Uronema marinum, a new and common parasite on tropical saltwater fishes. Freshw Mar Aquar 6: 78-81

Bradfold MA (1976) A rapid and sensitive method for the quantification of microgram quantities of protein utilizing the principle of protein-dye binding. Anal Biochem 72:248-254

Cheung PJ, Nigrelli RF, Ruggieri GD (1980) Studies on the morphology of Uronema marinum Dujardin (Ciliatea: Uronemmatidae) with a description of the histopathology of the infection in marine fishes. J Fish Dis 3:295-303

Davis P, Wheeler A (1985) The occurrence of Pampus argenteus (Euphrasen, 1788) in the North Sea. J Fish Biol 26: 105-109

Fenchel T (1968) The ecology of marine microbenthos. 2. The food of marine benthic ciliates. Ophelia 5:73-121

Foissner W (1992) The 'wet' silver nitrate method. In: Lee JJ, Soldo AT (eds) Protocols in protozoology. Society of Protozoologists, Allen Press, Lawrence, p C8.1-C8.5

Hamilton RD, Preslan JE (1969) Cultural characteristics of the pelagic marine hymenostome ciliate, Uronema sp. J Exp Mar Biol Ecol 4:90-99

Hatai K, Chukanhom K, Lawhavinit O, Hanjavanit C, Kunitsune M, Imai S (2001) Some biological characteristics of Tetrahymena corlissi isolated from guppy in Thailand. Fish Pathol 36:195-199

Kimball RF, Caspersson TO, Sevensson G, Carlson L (1959) Quantitative cytochemical studies on Paramecium aurelia. Exp Cell Res 17:160-172

Klemba M, Goldberg DE (2002) Biological roles of proteases in parasitic protozoa. Annu Rev Biochem 71:275-305

Kwon SR, Kim CS, Kim KH (2003) Differences between short and long term cultures of Uronema marinum (Ciliata: Scutic- 
ociliatida) in chemiluminescence inhibitory activity, oxidative enzyme and protease activity. Aquaculture 221:107-114

Lee EH, Kim CS, Cho JB, Ahn KJ, Kim KH (2003) Measurement of protease activity of live Uronema marinum (Ciliata: Scuticociliatida) by fluorescence polarization. Dis Aquat Org 54:85-88

McKerrow JH (1989) Minireview: parasite proteases. Exp Parasitol 68:111-115

McKerrow JH, Sun E, Rosenthal PJ, Bouvier J (1993) The protease and pathogenicity of parasitic protozoa. Annu Rev Microbiol 47:821-853

Munday BL, O'Donoghue PJ, Watts M, Rough K, Hawkesford $T$ (1997) Fatal encephalitis due to the scuticociliate Uronema nigricans in sea-caged southern bluefin tuna Thunnus maccoyii. Dis Aquat Org 30:17-25

North MJ (1992) The characteristic of cysteine proteases of parasitic protozoa. Biol Chem 373:401-406

Nottage AS, Birkbeck TH (1987) Purification of proteinase produced by the bivalve pathogen Vibrio alginolyticus NCMB 1339. J Fish Dis 10:211-220

Editorial responsibility: Robin Overstreet, Ocean Springs, Mississippi, USA
Ohman MD, Snyder RA (1991) Growth kinetics of omnivore oligotrich ciliate Strombidium sp. Limnol Oceanogr 36: 922-935

Parker JG (1976) Culture characteristics of the marine ciliated protozoan, Uronema marinum Dujardin. J Exp Mar Biol Ecol 24:213-226

Sherr BF, Sherr EB, Rassoulzadegan F (1988) Rates of digestion of bacteria by marine phagotrophic protozoa: temperature dependence. Appl Environ Microbiol 54: 1091-1095

Small HJ, Neil DM, Taylor AC, Coombs GH (2005) Identification and partial characterization of metalloproteases secreted by Mesanophrys-like ciliate parasite of the Norway lobster Nephrops norvegicus. Dis Aquat Org 67: 225-231

Watts M, Burke CM, Munday BL (1996) The development of fluorescent antibody stain to identify a Uronema sp. (Ciliophora: Scuticocilitida) implicated in fatal encephalitis in southern bluefin tuna (Thunnus macoyii). Bull Eur Assoc Fish Pathol 16:104-108

Submitted: April 27, 2006; Accepted: November 20, 2006 Proofs received from author(s): May 23, 2007 